\title{
Adsorption of Herbicide Diuron in Pineapple-Growing Soils of Eastern Thailand
}

\author{
Phongsakon Tantarawongsa, Daojarus Ketrot* \\ Department of Soil Science, Faculty of Agriculture, Kasetsart University, Chatuchak, \\ Bangkok, Thailand
}

Received: 13 October 2018

Accepted: 15 December 2018

\begin{abstract}
Four pineapple-growing soils (topsoil) were collected from Chonburi and Chachoengsao provinces in Thailand to analyze the physiochemical properties, chemical composition of organic carbon and diuron adsorption isotherm (batch experiment). Results revealed that diuron adsorption rate of soils was low (ranging between 1.81 and 27.63\%) and adsorption data fit well with Freundlich equation $\left(R^{2}=0.83-0.97\right)$, in which the adsorption coefficient $\left(K_{F}\right)$ is between 0.57 and $4.87 \mathrm{~L} \mathrm{~kg}^{-1}$. Soil organic matter and clay content were responsible for the adsorption of diuron in these soils $\left(r=0.95^{* *}\right.$ and $0.78^{* *}$, respectively). In addition, total nitrogen, silt content and cation exchange capacity also had a positive correlation with diuron adsorption in the soils. Organic carbon partitioning coefficient $\left(K_{O C}\right)$ of soils ranged from 125.84 to $480.36 \mathrm{~L} \mathrm{~kg}^{-1}$ and showed a positive correlation with the functional group of organic carbon, including aromatic carbon and carbonyl $\left(r=0.80^{* *}\right.$ and $0.67^{*}$, respectively). This low rate of diuron adsorption in pineapple-growing soils posed a risk in diuron contamination in the environment. The increase of organic matter in these soils, particularly those coarse to medium-textured soils, through proper soil management would increase the herbicide adsorption ability of these soils and should subsequently reduce the contamination markedly.
\end{abstract}

Keywords: diuron, adsorption, pineapple growing soils, soil organic matter

\section{Introduction}

Nowadays, social direction focuses on natural and organic farming, which bans or restricts the use of pesticides. However, chemicals such as herbicides and insecticides are still importantly essential in crop and livestock productions - particularly in the tropics, where severe outbreaks of weeds and pests are common and threaten the loss of such productions. Diuron $(N-(3,4-$

*e-mail: fagrdrk@ku.ac.th dichlorophenyl)- $N, N$-dimethylurea) is the main systemic phenyl urea herbicide which inhibits the photosynthesis at PS II of plants [1-2]. Diuron formulation is usually in wettable powder (WP) and suspension concentration (SC). It is a broad-spectrum residual herbicide registered for pre-emergence and post-emergence to control of both broadleaf and annual grassy weed [3]. The application of diuron has been directed moderately persistently in agricultural soil and water, air, organisms and other environments [4-7]. It could result in soil and water pollution and other ecological problems. For its toxicity, diuron is slightly toxic to mammals and birds, moderately toxic to aquatic invertebrates and exerts 
harmful effects on fetal development and damages human health [8-9].

Thailand is an agricultural-based country. Pineapple is one of main economic crops of the country. The average production of pineapple in Thailand is reportedly more than 1.7 million tons per year, which makes it one of the top five largest pineapple producers in the world [10]. In an attempt to reduce the incidence of pests, a large number of pesticides are usually applied for pineapple production. Diuron is one of the main herbicides, having been used by farmers in pineapple growing areas to control a wide range of weed such as Chick weed (Ageratum conyzoides) and Crowfoot grass (Dactyloctenium aegyptium) for more than 10 years [11]. However, the application is often inappropriate due to incorrect application techniques (e.g. overdosed rate as recommended and improperly mixed with other pesticides), poorly maintained or totally inappropriate spraying equipment, etc., which results in residue in plants, water sources and especially soil. Moreover, pineapples commonly requires well-drained soil that rapid leaching or vertical movement of water through the soil leads to increasing the risk of pesticide contamination in the environment.

The study on adsorption in soils is useful for understanding key processes that affect transportation, degradation and bioavailability of pesticides. Soil organic matter plays the main role in adsorption of hydrophobic organic compound of soils [12-13], and diuron molecules also have similar hydrophobicity characteristic [14]. Many studies have reported about diuron adsorption on many cultivated soils $[3,13,15]$, but there is a lack of information for pineapple growing soils which have a high risk of diuron environmental contamination. Thus, this study was carried out to investigate the adsorption behavior of diuron in pineapple-growing soils and the relationship between diuron adsorption and soil properties, especially soil organic matter. The finding will provide proper soil management guidance for lessening the risk of diuron contamination from pineapple growing areas to the environment.

\section{Material and Methods}

\section{Chemicals}

Technical-grade diuron (99\% purity) was purchased from Sigma-Aldrich in Germany. Physical and chemical properties of the diuron used are shown in Table 1. All other chemicals were analytical grade.

\section{Soil Sample Collection and Preparation}

Topsoil (Ap horizon; 0-20 cm) with three replicates of four pineapple growing soils were collected from farmers' pineapple growing areas in Chonburi and Chachoengsao provinces situated in eastern Thailand, where pineapple is grown extensively. Coordinates, site
Table 1. Physical and chemical properties of diuron [1-2].

\begin{tabular}{|c|c|}
\hline Properties & Diuron \\
\hline Structure & $330-54-1$ \\
\hline CAS numbers & 233.11 \\
\hline Molecular weight & Neutral \\
\hline $\mathrm{p} K_{a}$ & 42 \\
\hline Solubility $\left(\mathrm{mg} \mathrm{kg}^{-1}\right)$ & $648-747$ \\
\hline Octanol/water partition coefficient $\left(K_{\text {ow }}\right)$ & \\
\hline
\end{tabular}

description, soil parent material and soil classification were recorded as shown in Table 2. Soil samples were air-dried and sieved though 2.0 and $0.5 \mathrm{~mm}$ for the analysis of physicochemical properties, soil organic carbon composition and diuron adsorption.

\section{Physicochemical Analysis of Soils}

The particle size distribution was determined using the pipette method [17]. Mineral composition of whole soils and clay fractions were determined by X-ray diffraction method $(\mathrm{Cu} \mathrm{K \alpha}$ radiation at $35 \mathrm{kV})$ [18]. Chemical properties of soils were analyzed as described by [19] as follows: soil $\mathrm{pH}$ was measured in water using 1:1 (soil:water); soil organic matter was estimated by the determination of soil organic carbon (OC) (dichromate oxidation procedure) and then multiplied by 1.724 ; cation exchange capacity (CDC) was extracted with a $1 \mathrm{M} \mathrm{NH} \mathrm{NH}_{4} \mathrm{OAc}$ solution at $\mathrm{pH} 7.0$; total nitrogen was determined by Kjeldahl method; available phosphorus was determined by Bray II method; available potassium was extracted by $1 \mathrm{M} \mathrm{NH}_{4} \mathrm{OAc}(\mathrm{pH} 7.0)$ and analyzed using an atomic absorption spectrophotometer (AAS); electrical conductivity (ECe) was determined in a saturated paste extract.

\section{Chemical Composition of Soil Organic Carbon}

Soil samples were HF-treated basing on a procedure described by [20]. Briefly, the HF treatment consisted of nine successive treatments with $2 \%$ hydrofluoric acid solution. Each treatment involved shaking $3 \mathrm{~g}$ portions of soil and being shaken with $50 \mathrm{~mL}$ of $2 \%$ hydrofluoric acid solution $1 \mathrm{~h}$ (5 times), $16 \mathrm{hrs}$ (3 times) and $64 \mathrm{hrs}$ (once), respectively. Between treatments, the sample was centrifuged at $2,000 \mathrm{rpm}$ for $20 \mathrm{~min}$. After the final extraction, the soil residue was washed three times with distilled water, freeze-dried and then analyzed the functional group of organic carbon by CP-MAS ${ }^{13} \mathrm{C}$ nuclear magnetic resonance spectroscopy (NMR). 
Table 2. Location, province, district, parent material and classification of pineapple-growing soils.

\begin{tabular}{|c|c|c|c|c|c|}
\hline \multirow{2}{*}{ Soil sample } & \multicolumn{2}{|c|}{ Location } & \multirow{2}{*}{ District, Province } & Parent material ${ }^{\mathrm{a}}$ & Soil classification $^{\mathrm{a}}$ \\
\cline { 2 - 3 } & $\mathrm{X}$ & $\mathrm{Y}$ & Plaeng Yao, Chachoengsao & Shale and basalt & Ultisols \\
\hline CL & 763277 & 1493924 & Nong Yai, Chonburi & $\begin{array}{c}\text { Shale, siltstone and } \\
\text { sandstone }\end{array}$ & Ultisols \\
\hline SL & 767170 & 1448386 & Nong Yai, Chonburi & Shale & Ultisols \\
\hline SCL & 769190 & 1444879 & Nong Yai, Chonburi & Granite & Ultisols \\
\hline
\end{tabular}

a Source: [16]

\section{Adsorption Experiment}

Adsorption experiment was carried out using a batch equilibrium method. Diuron solution was prepared by dissolving weighed diuron in methanol and subsequently diluted it to different concentrations in DI water containing $0.01 \mathrm{M} \mathrm{CaCl}_{2}$ and $0.02 \% \mathrm{NaN}_{3}$. The triplicate samples of $2.5 \mathrm{~g}$ soil $(<2 \mathrm{~mm}$ size $)$ were placed in a $50 \mathrm{~mL}$ polypropylene centrifuge tube and mixed with $25 \mathrm{~mL}$ of diuron at different concentrations of $0.5,1.0,2.0,4.0,8.0,16$ and $32 \mathrm{mg} \mathrm{L}^{-1}$, respectively. The samples were shaken for $18 \mathrm{hrs}$ at $210 \mathrm{rpm}$, then centrifuged at $10,000 \mathrm{rpm}$ for $10 \mathrm{~min}$. The supernatant was decanted and filtered using $0.45 \mu \mathrm{m}$ syringe filters. Diuron equilibrium concentrations $\left(C_{e}\right)$ were determined by ultra-high performance liquid chromatography (UHPLC) Series 1290 (Agilent, U.S.A.) equipped with a diode-array detector at $250 \mathrm{~nm}$. The column was Merck C18 $(4.6 \mathrm{~mm} \times 250 \mathrm{~mm} \times 5 \mu \mathrm{m})$. The flow phase was acetonitrile: distilled water $(60: 40, \mathrm{v} / \mathrm{v})$. The injection volume was $20 \mu \mathrm{L}$. The total run time was $10 \mathrm{~min}$. The retention time of diuron was $4.61 \mathrm{~min}$.

Adsorption data were fitted to the Freundlich model (Eq. (1)) in $\log$ format, $\log K_{F}$ and $1 / n$ are the adsorption parameters calculated from the linear regression (Eq. (2))

$$
\begin{gathered}
C_{s}=K_{F} C_{e}^{1 / n} \\
\log C_{s}=\log K_{F}+1 / n \log C_{e}
\end{gathered}
$$

...where the Freundlich adsorption isotherm represents the relationship between the corresponding adsorption capacity $C_{s}\left(\mathrm{mg} \mathrm{kg}^{-1}\right)$ and the concentration of the diuron in solution at equilibrium $C_{e}\left(\mathrm{mg} \mathrm{L}^{-1}\right)$. The $K_{F}$ is the adsorption coefficient, and value $n$ represents the energy distribution of adsorption sites.

The organic carbon partitioning coefficient $\left(K_{O C}\right)$ was also calculated as a function of $K_{F}$ and organic carbon content in soils as the following Equation (3).

$$
K_{O C}=\left(K_{F} / \% \mathrm{OC}\right) \times 100
$$

\section{Statistical Analysis}

Statistical evaluation was performed using Pearson correlation test (two-tailed) to study the relationship between the adsorption data and soil properties.

\section{Results and Discussion}

\section{Physicochemical Property of Four Pineapple-Growing Soils}

The physicochemical property of four soils collected from pineapple growing is summarized in Table 3. There were sandy loam (SL) and loamy sand (LS) soils represented by coarse-textured soil, a sandy clay loam (SCL) soil represented by medium-textured soil, and a clay loam (CL) soil representing finetextured soil. Mineralogical property of whole soils showed that quartz was a dominant mineral, whereas kaolinite was a major clay mineral in clay fraction of all soils, which was common in highly weathered soil, especially in Ultisols [21]. Moreover, whole soils and clay fraction in this study also contained trace amounts of montmorillonite, illite, anatase, muscovite, zircon, microcline and dolomite.

The $\mathrm{pH}$ of SL, SCL and LS soils were extremely acid, but the CL soil was moderately acid. Soil organic matter and total nitrogen of all soils were low; however, the CL soil had a higher value than did the other soils. Cation exchange capacity of these soils was very low (1.11-1.96 $\left.\mathrm{cmol}_{\mathrm{c}} \mathrm{kg}^{-1}\right)$, except for CL soil that had moderately low value $\left(6.28 \mathrm{cmol}_{\mathrm{c}} \mathrm{kg}^{-1}\right)$, which was consistent with organic matter content and mineralogical properties of soils. Available phosphorus was medium to very high (13.97-112.41 $\left.\mathrm{mg} \mathrm{kg}^{-1}\right)$ and available potassium was very low in SL, SCL and LS soils $\left(12.42-24.76 \mathrm{mg} \mathrm{kg}^{-1}\right)$, but the $\mathrm{CL}$ soil had a very high value $\left(544.72 \mathrm{mg} \mathrm{kg}{ }^{-1}\right)$. Electrical conductivity was in the rage of $0.21-2.08 \mathrm{dS} \mathrm{m} \mathrm{m}^{-1}$, therefore they were non-saline soils. Most studied soils had a low soil $\mathrm{pH}$, organic matter, cation exchange capacity and total nitrogen because they are highly weathered soils and basic cations were leached. However, the increase of available phosphorus and 


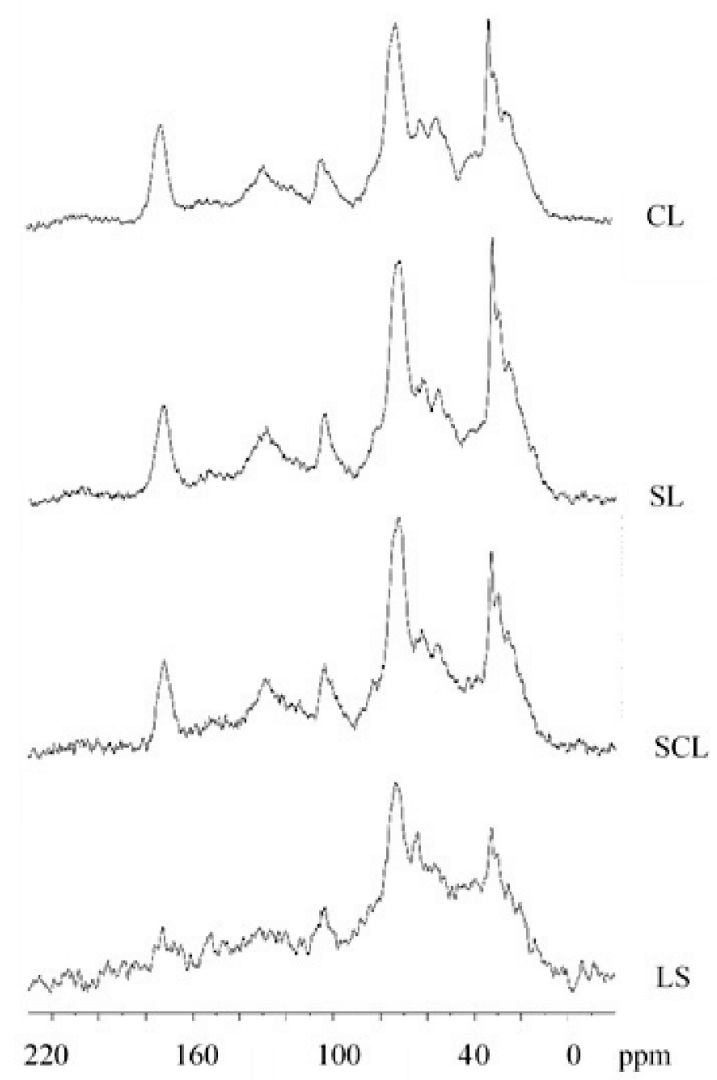

Fig. 1. Solid-state ${ }^{13} \mathrm{C}$ NMR spectra of pineapple-growing soils.

available potassium may be influenced by fertilization and intensive agricultural practices.

\section{Chemical Composition of Organic Carbon}

Results of ${ }^{13} \mathrm{C}$ NMR spectra and relative proportions of organic carbon are shown in Fig. 1 and Table 4, respectively. All soil samples had the highest O-alky carbon content (at 45-110 ppm) in the range of 47.71-58.81\%, which was similar to that of forest and paddy soils [22-23]. The dominant signal of this region was found at $72 \mathrm{ppm}$ and $104 \mathrm{ppm}$, which was assigned

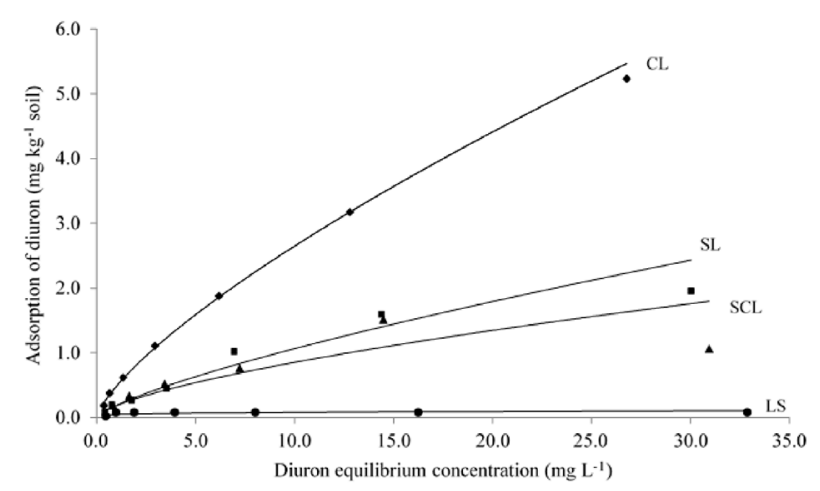

Fig. 2. Adsorption curve of diuron in four pineapple-growing soils. as polysaccharide [24]. The signal at 104, which was between $95 \mathrm{ppm}$ and $112 \mathrm{ppm}$, was also the signal region of sugar (alkyl O-C-O) [25]. Moreover, at signal $56 \mathrm{ppm}$, it represented the carbon from methoxyl group derived from lignin and $\alpha$-protein [26].

Alkyl carbon (at 0-45 ppm) was the secondhighest organic carbon content in the studied soils with the amounts ranging between 24.07 and $31.59 \%$. It was carbon that derived from long chain of lipid and peptide [27]. In addition, at signal $33 \mathrm{ppm}$, carbon from crystalline and amorphous polymethylene $\left(-\mathrm{CH}_{2}-\right)$ was presented [28]. Aromatic carbon (at $110-160 \mathrm{ppm}$ ) was found in the range of $4.16-14.37 \%$, which was the third highest amount of organic carbon in these soils, with the exception of that in LS soil. Carbon in this signal region was derived from lignin (at $129 \mathrm{ppm}$ ), which was found near $125 \mathrm{ppm}$ signal (Exomethylenes, $-\mathrm{C}=\mathrm{CH}_{2}$ ) [29]. Due to no burning of crop residues in pineapple cultivation, these pineapple-growing soils had a smaller signal of aromatic carbon than did banana plantation and forest soils (19-35\%) [22]. This was because high content of aromatic carbon in soils arose from fire or burning of plant biomass, which accelerated oxidation processes [22, 30-31]. For the carbonyl carbon (at 160-190 ppm), it was very low in all soil samples (7.22-9.26\%) and was found in carboxylic acid (-COOH) dominant peak at $173 \mathrm{ppm}$ [25].

\section{Diuron Adsorption}

Diuron adsorption curve and data of four pineapplegrowing soils are presented in Fig. 2 and Table 5, respectively. Results showed that $27.63 \%$ of diuron was adsorbed in CL soil, of which this soil had the highest organic matter content, while respective amounts of $12.77 \%, 12.00 \%$ and $1.81 \%$ were adsorbed in SL, SCL and LS soils. The adsorption data fitted well with the Freundlich model. The CL, SL and SCL soils showed an L-type isotherm $(n>1)$, indicating that diuron could also adsorb onto the clay fraction apart from organic matter, whereas the LS soil showed a C-type isotherm $(n<1)$, demonstrating that the adsorption of diuron in this soil was mainly a partition between soil organic matter and soil solution [3]. The adsorption coefficient $\left(K_{F}\right)$ ranged from 0.57 to $4.87 \mathrm{~L} \mathrm{~kg}^{-1}$ with high regression coefficients $\left(R^{2}=0.83-0.97\right)$. The adsorption rate and the $K_{F}$ indicated the adsorption of diuron in soils being in the sequence of $\mathrm{CL}>\mathrm{SL}>\mathrm{SCL}>\mathrm{LS}$.

\section{Relationship between Diuron Adsorption and Soil Properties}

The $K_{F}$ of four pineapple-growing soils in this study statistically had a significant positive correlation with contents of organic matter, total nitrogen, silt content, cation exchange capacity and clay content $\left(r=0.95^{* *}\right.$, $0.93^{* *}, 0.90^{* *}, 0.80^{* *}$ and $0.78^{* *}$, respectively), but it negatively correlated with sand content $\left(r=-0.90^{* *}\right)$, as illustrated in Table 6 . The organic matter played 
Table 3. Average values of physicochemical properties of pineapple-growing soils.

\begin{tabular}{|c|c|c|c|c|}
\hline \multirow{2}{*}{ Properties } & \multicolumn{4}{|c|}{ Soil sample } \\
\hline & $\mathrm{CL}$ & SL & SCL & LS \\
\hline Soil texture & Clay loam & Sandy loam & Sandy clay loam & Loamy sand \\
\hline Sand $\left(\mathrm{g} \mathrm{kg}^{-1}\right)$ & 252 & 738 & 697 & 800 \\
\hline Silt $\left(\mathrm{g} \mathrm{kg}^{-1}\right)$ & 437 & 149 & 101 & 106 \\
\hline Clay $\left(\mathrm{g} \mathrm{kg}^{-1}\right)$ & 311 & 113 & 202 & 94 \\
\hline Mineralogy of whole soil & $\begin{array}{c}\text { Quartz }^{\mathrm{a}} \\
\text { Kaolinite }^{\mathrm{e}} \\
\text { Anatase }^{\mathrm{e}} \\
\text { Muscovite }^{\mathrm{e}}\end{array}$ & $\begin{array}{l}\text { Quartza }^{\mathrm{a}} \\
\text { Zircon }^{\mathrm{e}}\end{array}$ & $\begin{array}{c}\text { Quartz }^{\mathrm{a}} \\
\text { Kaolinite }^{\mathrm{e}} \\
\text { Dolomite }^{\mathrm{e}}\end{array}$ & $\begin{array}{c}\text { Quartza }^{\mathrm{a}} \\
\text { Microcline }^{\mathrm{e}}\end{array}$ \\
\hline Mineralogy of clay fraction & $\begin{array}{c}\text { Kaolinite }^{\mathrm{c}} \\
\text { Montmorillonite }^{\mathrm{d}} \\
\text { Quartz }^{\mathrm{d}}\end{array}$ & $\begin{array}{c}\text { Kaolinite }^{\mathrm{b}} \\
\text { Quartz }^{\mathrm{d}} \\
\text { Montmorillonite } \\
\text { Illite }^{\mathrm{e}}\end{array}$ & $\begin{array}{l}\text { Kaolinite }^{\mathrm{a}} \\
\text { Quartz }^{\mathrm{e}}\end{array}$ & $\begin{array}{l}\text { Kaolinite }^{\mathrm{b}} \\
\text { Quartz }^{\mathrm{d}} \\
\text { Illite }^{\mathrm{e}}\end{array}$ \\
\hline Soil pH 1:1 (soil: $\left.\mathrm{H}_{2} \mathrm{O}\right)$ & 5.79 & 3.92 & 3.74 & 3.83 \\
\hline Soil organic matter $\left(\mathrm{g} \mathrm{kg}^{-1}\right)$ & 2.25 & 0.69 & 0.97 & 0.79 \\
\hline $\operatorname{CEC}\left(\mathrm{cmol}_{\mathrm{c}} \mathrm{kg}^{-1}\right)$ & 6.28 & 1.96 & 1.81 & 1.11 \\
\hline Total N $\left(\mathrm{g} \mathrm{kg}^{-1}\right)$ & 1.54 & 0.37 & 0.28 & 0.21 \\
\hline Avail. P (mg kg-1) & 87.95 & 13.97 & 17.70 & 112.41 \\
\hline Avail. K (mg kg-1) & 544.72 & 19.67 & 12.42 & 24.76 \\
\hline $\mathrm{ECe}\left(\mathrm{dS} \mathrm{m} \mathrm{m}^{-1}\right)$ & 1.69 & 0.59 & 0.21 & 2.08 \\
\hline
\end{tabular}

${ }^{\mathrm{a}}$ dominant; ${ }^{\mathrm{b}}$ large; ${ }^{\mathrm{c}}$ moderate; ${ }^{\mathrm{d}}$ small; ${ }^{\mathrm{e}}$ trace

a major role in affecting the adsorption of diuron in these soils because non-polar and hydrophobicity $\left(K_{o w}=\right.$ 700 ) of diuron made the organic matter adsorb diuron by partition mechanism [3]. This finding was in agreement with [3], who reported that soil organic matter content plays an important role in the adsorption and desorption of diuron. The SL and SCL soils had similar diuron adsorption rates and also organic matter content. For LS soil, it showed the lowest diuron adsorption rate, although it had a similar organic matter content with SL and SCL soils. This was due to the LS soil having low clay content as this soil particle, having a small particle size and high specific surface area, also partly affected the adsorption rate. Furthermore, clay fraction adsorbed diuron more than bulk soils, sand and silt fractions due to their higher soil organic carbon content [32]. In contrast, the SL soil had less clay content than did the SCL soil, but the former had a slightly higher diuron adsorption rate than did the latter. In this case, dolomite, which the SCL soil contained small amount of dolomite, should play a part in the adsorption [33]. In addition, cation exchange capacity also had a positive effect on diuron adsorption because this soil property was closely related to soil organic matter and clay content. This was consistent with the studies of [3], who found that the adsorption of diuron had a relationship with cation exchange capacity.

Soil $\mathrm{pH}$ has no significant effect on the adsorption of diuron because diuron is a non-ionic pesticide [13]; nevertheless, it affects variable surface charges of organic matter and clay mineral in soil [34]. In addition, it has been reported that potassium chloride can increase the adsorption of diuron in smectite due to the increase of available potassium-added ionic strength to cause a reduction of water available, effecting the attraction of diuron by solid phase of soils [35]. However, the diuron

Table 4. Proportions of each carbon region in NMR spectra (\%).

\begin{tabular}{|c|c|c|c|c|}
\hline $\begin{array}{c}\text { Soil sam- } \\
\text { ple }\end{array}$ & Alkyl (0-45 ppm) & O-alkyl (45-110 ppm) & Aromatic carbon (110-160 ppm) & Carbonyl (160-190 ppm) \\
\hline CL & 31.37 & 47.71 & 11.81 & 9.11 \\
\hline SL & 26.12 & 50.25 & 14.37 & 9.26 \\
\hline SCL & 24.07 & 58.81 & 9.90 & 7.22 \\
\hline LS & 31.59 & 56.25 & 4.16 & 8.01 \\
\hline
\end{tabular}


Table 5. Adsorption parameters of diuron in pineapple-growing soils.

\begin{tabular}{|c|c|c|c|c|c|}
\hline \multirow{2}{*}{$\begin{array}{c}\text { Soil } \\
\text { sample }\end{array}$} & \multirow{2}{*}{$\begin{array}{c}\text { Adsorption } \\
\text { rate } \\
(\%)\end{array}$} & \multicolumn{3}{|c|}{ Freundlich model } & \multirow{2}{*}{$\begin{array}{c}K_{O C} \\
\left(\mathrm{~L} \mathrm{~kg}^{-1}\right)\end{array}$} \\
\cline { 3 - 5 } & $\begin{array}{c}K_{F} \\
\left(\mathrm{~L} \mathrm{~kg}^{-1}\right)\end{array}$ & $n$ & $R^{2}$ & \\
\hline CL & 27.63 & 4.87 & 1.37 & 0.97 & 377.51 \\
\hline SL & 12.77 & 1.86 & 1.35 & 0.95 & 480.36 \\
\hline SCL & 12.00 & 1.82 & 1.59 & 0.83 & 324.95 \\
\hline LS & 1.81 & 0.57 & 0.85 & 0.89 & 125.84 \\
\hline
\end{tabular}

adsorption in four pineapple-growing soils in this present study was not affected by available potassium, available phosphorus and ECe.

\section{Correlation between Organic Carbon Partitioning Coefficient $\left(K_{O C}\right)$ and Functional Group of Organic Carbon}

Organic carbon partitioning coefficient $\left(K_{O C}\right)$ ranged from 125.84 to $480.36 \mathrm{~L} \mathrm{~kg}^{-1}$ (Table 5) and had a significantly positive correlation with a functional group of organic carbon, including aromatic carbon and carbonyl $\left(r=0.80^{* *}\right.$ and $0.67^{*}$, respectively) (Fig. 3). However, it negatively correlated with O-alky and alkyl carbon ( $r=-0.65^{*}$ and $-0.21^{*}$, respectively) (Fig. 3). Although aromatic carbon content in soil organic carbon structure was very low, it had the most effect on the $K_{O C}$ of diuron because the aromatic carbon is non-polar carbon and diuron is non-ionic pesticide. This was consistent with [30], who found that the aromatic carbon had a positive correlation with the $K_{O C}$ of five pesticides (Imidacloprid, Clothianidin, Thiacloprid, Methidathion and Chlorpneb). Likewise, [15] showed a positive correlation between the aromatic carbon and the $K_{O C}$ of diuron and a negative correlation between $\mathrm{O}$-alkyl carbon and Alkyl carbon.

\section{Conclusions}

Diuron adsorption in four pineapple-growing soils was in the range $1.81-27.63 \%$, and the adsorption data fit well with the Freundlich model. Soil organic matter

Table 6. The correlation coefficients $(r)$ between the adsorption coefficient $(K)$ and soil properties

\begin{tabular}{|c|c|c|c|c|c|c|c|c|c|c|}
\hline Parameter & Sand & Silt & Clay & $\mathrm{pH}$ & OM & CEC & Total. N & Avail. P & Avail. K & ECe \\
\hline$K_{F}$ & $-0.90^{* * *}$ & $0.90^{* *}$ & $0.78^{* *}$ & 0.53 & $0.95^{* *}$ & $0.80^{* *}$ & $0.93^{* *}$ & 0.18 & -0.53 & 0.22 \\
\hline
\end{tabular}

**Correlation is significant at the 0.01 level (2-tailed).
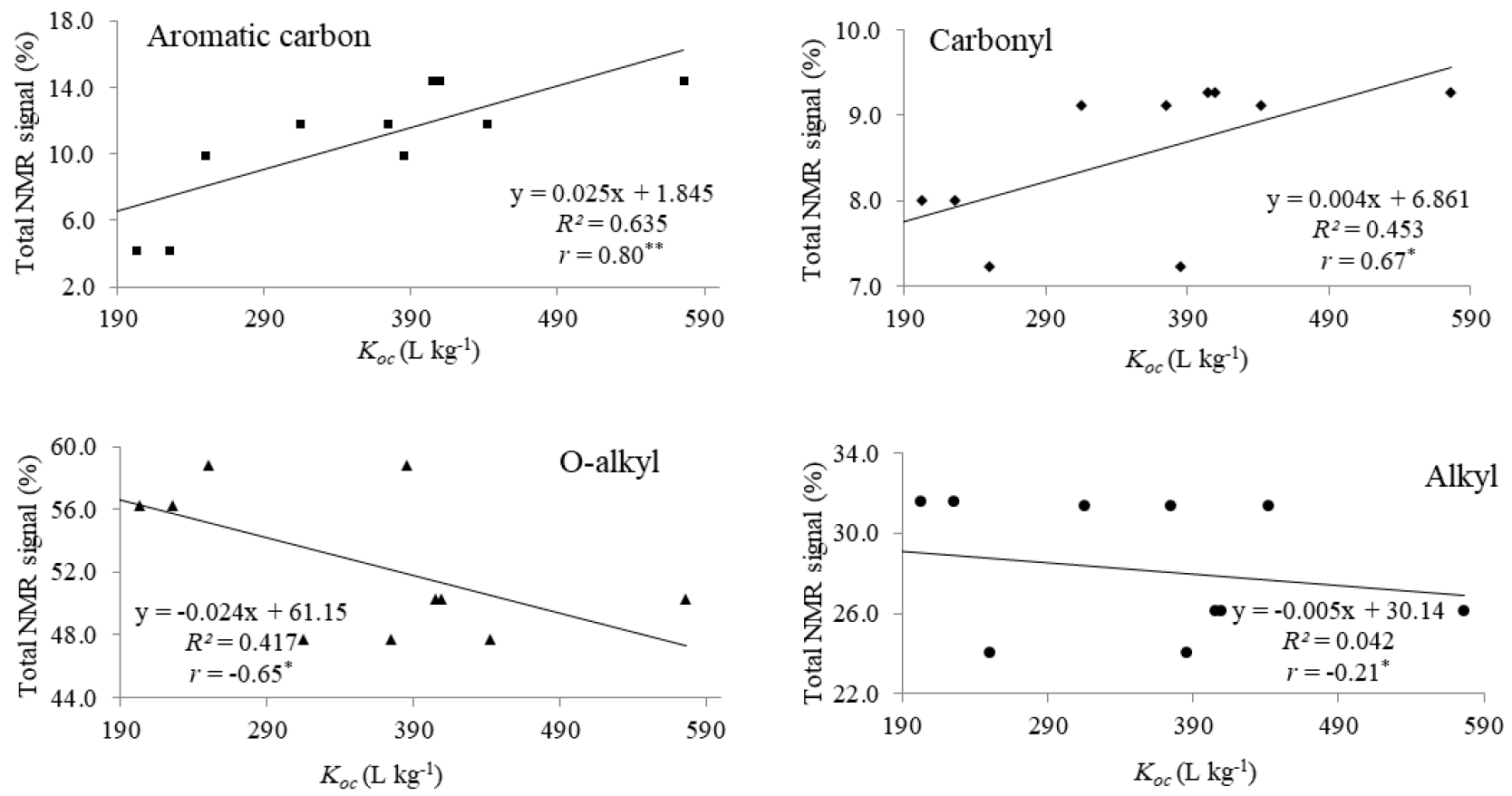

Fig. 3. Correlation coefficients $(r)$ for organic carbon partitioning coefficient $\left(K_{\mathrm{oc}}\right)$ of pineapple-growing soils and percentage of total NMR sign.

* Correlation is significant at the 0.05 level (2-tailed).

** Correlation is significant at the 0.01 level (2-tailed). 
and clay content were the main factor that influenced the adsorption of diuron in these soils, although the soils had low soil organic matter and clay contents. Total nitrogen, silt content and cation exchange capacity had a positive correlation with diuron adsorption in these soils, but sand content showed otherwise. Organic carbon partitioning coefficient of the soils had a significantly positive correlation with aromatic carbon and carbonyl in soil organic matter; however, it negatively correlated with O-alky carbon and alkyl carbon. Low diuron adsorption in these pineapple-growing soils posed a risk of diuron and perhaps other pesticides used in the cultivation contamination in the environment. A proper practice on increasing organic matter content in these soils would be ideal in terms of decreasing this risk.

\section{Acknowledgements}

This research is supported by the Graduate Program Scholarship from the Graduate School, Kasetsart University. The authors are grateful to Pesticide Research Group, Agricultural Production Science Research and Development Office, Department of Agriculture, Ministry of Agriculture and Cooperatives for diuron analysis and to Soil Mineralogy and Soil Micromorphology Research Division, Land Development Department for XRD analysis.

\section{Conflict of Interest}

The authors declare no conflict of interest.

\section{References}

1. Herbicide Resistance Action Committee, HRAC classification on mode of action 2010. Available online: http://hracglobal.com/files/moaposter.pdf (accessed 09/2018)

2. Environmental Fate of Diuron. Pesticide Chemistry Database, Department of Pesticide Regulation. Available online: https://www.cdpr.ca.gov/docs/emon/pubs/ fatememo/ diuron.pdf (accessed 09/2018).

3. LIU Y., XU Z., WU X., GUI W., ZHU G. Adsorption and desorption behavior of herbicide diuron on various Chinese cultivated soils. Journal of Hazardous Materials, 178, 462, 2010.

4. HU Q., LONG Z., PING H., XI-YI Z., WEI-BIN JIA, SHUN-PENG L., JIAN-DONG J. Xinfangfangia soli gen. nov., sp. nov., isolated from a diuron polluted soil. Journal of Systematic and Evolutionary Microbiology, 68, 2622, 2018.

5. MANSANO A.S., RAQUEL A.M., MAYARA P., THIESSA M.A.O., ENY M.V., ODETE R., MIRNA H.R.S. Effects of diuron and carbofuran pesticides in their pure and commercial forms on Paramecium caudatum: The use of protozoan in ecotoxicology. Environmental Pollution, 213, 160, 2016.

6. MUENDO B.M., LALAH J.O., GETENGA Z.M. Behavior of pesticide residues in agricultural soil and adjacent River Kuywa sediment and water samples from Nzoiasugarcane belt in Kenya. Environmentalist, 32, 433, 2012.

7. MUHAMAD H., RAMLI M.I., ZAKARIA Z., SAHID I. The fate of diuron in soil in a Malaysian Oil Palm Plantation. Journal of Oil Palm Research, 25, 149, 2013.

8. GIACOMAZZI S., COCHET N. Environmental impact of diuron transformation: a review. Chemosphere, 56, 1021, 2004.

9. HUOVINEN M., LOIKKANEN J., NAARALA J., VAHAKANGAS K. Toxicity of diuron in human cancer cells. Toxicology in Vitro, 29, 1577, 2015.

10. Food and agriculture organization of the United Nations. 2016. Available online: http://www.fao.org/faostat/ en/\#rankings/countries_by_commodity 09/2018).

11. PORNPROM T. Herbicides: principles and mode of action. Chulalongkorn University Press, Bangkok, Thailand, 2011. [In Thai].

12. SUN K., BO G., KYOUNG S.R., JEFF M.N., ZIYING W., STEPHEN H., BAOSHAN X. Assessment of herbicide sorption by biochars and organic matter associated with soil and sediment. Environmental Pollution, 163, 167, 2012.

13. EI-NAHHAL Y., ABADSA M., AFFIFI S. Adsorption of diuron and linuron in Gaza soils. American Journal of Analytical Chemistry, 4, 94, 2013.

14. CACERES-JENSEN L., JORGE R.B., JOSELYN P.R., MAURICIO E., LORENA B., VICENTE C.C. Sorption kinetics of diuron on volcanic ash derived soils. Journal of Hazardous Materials, 261, 602, 2013.

15. SMERNIK R.J., KOOKANA R.S. The effects of organic matter-mineral interactions and organic matter chemistry on diuron sorption across a diverse range of soils. Chemosphere, 119, 99, 2015.

16. LAND DEVELOPMENT DEPARTMENT. Characterization of Established Soil Series of Thailand Reclassified According to Soil Taxonomy 2003. Bangkok, Thailand, 2004.

17. SOIL SURVEY STAFF. Obsolete methods, part IV: SSIR No. 1, Procedures for collecting soil samples and methods of analysis for soil survey. In Kellogg soil Survey Laboratory Methods Manual, Soil Survey Investigations Report No. 42, Version 5.0; Burt R., Soil Survey Staff Eds, USDA-NRCS, GPO, Washington, DC, 891, 2014.

18. WHITTING L.D., ALLARDICE W.R. X-ray diffraction techniques. In Methods of Soil Analysis. Part I: Physical and mineralogical methods-Agronomy monograph no. 9, $2^{\text {nd }}$ ed.; Klute A., Ed. Madison, WI, 331, 1986.

19. SPARKS D.L., PAGE A.L., HELMKE P.A., LOEPPERT R.H. Methods of Soil Analysis Part 3-Chemical Methods. SSSA Book Ser. 5.3. SSSA, ASA, Madison, WI, 1996.

20. CHURCHMAN G.J., FOSTER R.C., ACQUI L.P., JANIK L.J. SKJEMSTAD J.O., MERRY R.H., WEISSMAN N. Effect of land-use history on the potential for carbon sequestration in an Alfisol. Soil and Tillage Research, 109, 23, 2010.

21. KHAWMEE K., SUDDHIPRAKARN A., KHEORUENROMNE I., SINGH B. Surface charge properties of kaolinite from Thai soils. Geoderma, 192, 120, 2013.

22. RUMPEL C., ALEXIS M., CHABBI A., CHAPLOT V., RASSE D.P., VALENTIN C., MARIOTTI A. Black carbon contribution to soil organic matter composition 
in tropical sloping land under slash and burn agriculture. Geoderma, 130, 35, 2006.

23. YAN X., ZHOU H., ZHU Q.H., WANG X.F., ZHAN Y.Z., YU X.C., PENG X. Carbon sequestration efficiency in paddy soil and upland soil under long-term fertilization in southern China. Soil \& Tillage Research, 130, 42, 2013.

24. KOGEL-KNABNER I. ${ }^{13} \mathrm{C}$ and ${ }^{15} \mathrm{~N}$ NMR spectroscopy as a tool in soil organic matter studies. Geoderma, 80, 243, 1997.

25. MAO J., CAO X., OLK D.C., CHU W., SCHMIDT-ROHR K. Advanced solid-state NMR spectroscopy of natural organic matter. Progress in Nuclear Magnetic Resonance Spectroscopy, 100, 17, 2017.

26. ZHANG P., YANXIA W., YANG L., JIANMIN G., YAO C., YONGMING F. Heat-Induced Discoloration of Chromophore Structures in Eucalyptus Lignin. Materials, 11, 1686, 2018

27. KNICKER H., LÜDEMANN H.D. N-15 and C-13 CPMAS and solution NMR studies of $\mathrm{N}-15$ enriched plant material during 600 days of microbial degradation. Organic Geochemistry, 23, 329, 1995.

28. MAO J., NA C., XIAOYAN C. Characterization of humic substances by advanced solid state NMR spectroscopy: Demonstration of a systematic approach. Organic Geochemistry, 42, 891, 2011.

29. HELMS J.R., KONG X., SALMON W., HATCHER P.G., SCHMIDT-ROHR K., MAO J. Structural characterization of gilsonite bitumen by advanced nuclear magnetic resonance spectroscopy and ultrahigh resolution mass spectrometry revealing pyrrolic and aromatic rings substituted with aliphatic chains. Organic Geochemistry, 44, 21, 2012.

30. MOTOKI Y., IWAFUNE T., SEIKR N., OTANI T., ASANO M. Effects of organic carbon quality on the sorption behavior of pesticides in Japanese soils. Journal of Pesticide Science, 39 (2), 105, 2014.

31. NÄTHE K., LEVIA D.F., STEFFENS M., MICHALZIK B. Solid-state ${ }^{13} \mathrm{C}$ NMR characterization of surface fire effects on the composition of organic matter in both soil and soil solution from a coniferous forest. Geoderma, 305, 394, 2017.

32. WANG P., KELLER A.A. Sorption and desorption of atrazine and diuron onto water dispersible soil primary size fraction. Water Research, 43, 1448, 2009.

33. KASOZI G.N.K., KIZZA P.N., BIRIKORANG S.A., ZIMMERMAN A.R. Characterization of adsorption and degradation of diuron in carbonatic and noncarbonatic soils. Journal of Agricultural and Food Chemistry, 58 (2), 1055, 2010.

34. POLATI S., ANGIOIL S., GIANOTTI V., GOSETTI F., GENNARO M.C. Sorption of pesticide on kaolinite and montmorillonite as a function of hydrophilicity. Journal of environmental science and health part B, 41 (4), 333, 2006.

35. LI H., TEPPEN B.J., LAIRD D.A., JOHNSTON C. T., BOYD S.A. Effects of increasing potassium chloride and calcium chloride ionic strength on pesticide sorption by potassium- and calcium-smectite. Soil Science Society of America Journal, 70, 1889, 2006. 